\title{
A Model of Competitiveness of Coastal Women's Micro-Small Businesses in South Sulawesi
}

\author{
Nursini Nursini ${ }^{1}$, Muhammad Abduh Ibnu Hadjar², and Sri Undai Nurbayani ${ }^{1}$ \\ \{nini_mahmud@yahoo.com ${ }^{1}$, ibnuhajar_unhas@yahoo.com ${ }^{2}$, sri.undai@gmail.com ${ }^{3}$ \} \\ Faculty of Economics and Business, Hasanuddin University, Makassar, Indonesia ${ }^{1,3}$ \\ Faculty of Fisheries and Marine, Hasanuddin University, Makassar, Indonesia ${ }^{2}$
}

\begin{abstract}
This study aims to analyze the competitiveness of small micro business for coastal women and to design a model for increasing the competitiveness of their businesses. The research analysis units were a woman or group of women who run small microenterprises taking raw materials from fisheries and marine products. Primary data and secondary data were analyzed through descriptive statistical approaches. The findings of this study include (1) in generally, the competitiveness of women's Small Micro Enterprises (WSMEs) living on the coast which was still relatively low caused by the limited coverage of market and the too simple technology production. (2) a model of increasing competitiveness for women's SMEs based on a systems was required. To improve the competitiveness of small micro-business products for women living on the coast, there should be an effective synergy of programs offered by competent institutions such as universities, business, government, financial, and community.
\end{abstract}

Keywords:

Competitiveness, Model, Women, Small Micro Business, Coastal Area

JEL Clasification: L26; L66; 010; Z13; O25

Article Received: 18 October 2020, Revised: 3 November 2020, Accepted: 24 December 2020

\section{Introduction}

Micro, small and medium enterprise (MSME) that are experiencing rapid development at this time are a great medium to overcome the problem of poverty. During the period of 20122017, the contribution of the MSME sector to Gross Domestic Products (GDP) was 78,27 percent and absorbed labor by an average of 112,7 million people (BPS, 2018). The large contribution of MSMEs is in line with the large potential of MSME resources that are scattered throughout Indonesia and the role of institutions that have been involved including banking institutions and non-banking institutions.

Along with various strategies implemented to develop MSMEs, in South Sulawesi Province the types of most developed businesses are micro and small enterprises (MSEs). In 2014, the number of MSEs was 106,419 units and the number of workers absorbed was 236,069. In 2015, the number of MSEs increased to 118,473 units with a total workforce of 245,981 . This shows that the role of the MSE sector is very important in driving the economy, which in turn contributes to overcoming poverty. Some MSEs are operated by men and some by women. With the development of business units both micro and small and medium scale, the competition has become even tighter. Here are the main challenges and problems faced by general MSEs, especially women.

What is interesting to observe in this study are micro and small business actors because in general the majority are operated by women, especially in coastal areas. The high interest of women in opening small micro businesses shows that the level of women's participation in development is increasing. However, studies related to small microenterprises of women especially coastal women MSEs did not appear to get the big attention of researchers. This is reinforced by the lack of empirical studies on MSEs for women. The empirical study that is commonly found is the study of MSMEs in aggregate both for cross- 
national and national and local cases (Sakur 2011; Hamzani, and Achmad 2016; and Bappenas -National Development Planning Agency 2014).

The types of MSEs that have developed in coastal areas are fisheries-based MSEs, both fisheries and marine, and aquaculture. This is driven by the abundant potential of the fisheries sub-sector in South Sulawesi. It has been generally believed that micro and small enterprises developed by women in coastal areas that use raw materials from fisheries, in general, are still a side job so that attention to productivity, product quality, and competitiveness are still low. As a result, female MSEs in coastal areas have a quite serious problem of poverty. Basically, the productive economic activities carried out by coastal women have good market prospects but are still threatened by various problems and challenges especially in the era of Asian Economic Society (Bekele, and Worku 2008).

The MSME empowerment model that has been carried out by various parties so far is quite large and very varied, but still uses a partial approach and has not synergized with each other, so the results are not optimal. This indicates that the empowerment model has not been based on the real needs of the community and both MSME actors and MSEs tend to be uniform. While the empowerment program that focuses on increasing the competitiveness of MSE products developed by coastal women is still very limited. As a result, female MSEs in coastal areas, in general, are still difficult to get out of the problem of poverty. Samwel (2014) found that women's micro-small businesses play an important role in encouraging households to access basic needs such as food, housing, education and health. Therefore, this study aims to (1) analyze the competitiveness of small micro-enterprises of coastal women in South Sulawesi Province by focusing the surveys in Bone and Jeneponto Districts, (2) analyze the problems and challenges faced by MSEs of coastal women in developing their businesses, and (3) design a model for increasing MSE competitiveness for coastal women.
Survey Literature

Nowadays, the number of Small Micro Enterprises inclined rapidly in Indonesia and it is noticeable that majority of their products are homogeny. This fact indicates that they need to face high competition in marketing their output. As a consequence, producers are demanded to create superior and competitive products. The concept of competitiveness is firstly introduced by Porter (1990). He said that competitiveness is an ability to produce goods and services which are influenced by (1) Resources factor; (2) Demand; (3) Availability of complementary industry; and (4) Strategy, structure, and competition of business. Furthermore, report of Indonesian Bank states that the main factors influencing competitiveness of Small Micro Enterprises are (i) Internal factors: productivity and innovation; (ii) External factors; (iii) Ease of doing business; (iv) Financial Access; (v) Market Access; (vi) Infrastructure support; and (vii) Business cycle. Competitiveness of Small Medium Enterprises (SMEs) can be measured from the enhancement of the number of output produced (Atkinson 2013). This enhancement has an impact on the escalation of business's income.

Generally, there are many empirical studies which examined about Small Micro Enterprises but have resulted in various findings (BaptisteCornelis, and Long 2006, Rahmana 2009, Niode 2009, Agyapong 2010, Sakur 2011, Andharini 2012, Putu Darya 2012, Darwanto 2013, Ali et al. 2014, Setyanto et al. 2015, Ahmedova 2015, Sipa et al. 2015, and most recently Indonesian Bank 2016, and Hamzani 2016). This is caused by many factors, either from internal factor or external factor. Putu Darya (2012) had analyze SMEs competitiveness in Balikpapan and found that SMEs are not competitive yet due to inefficient of business management. This fact indicates that internal factor of SMEs such as human resources and institutional play an important role in improving business competitiveness. This statement is in line with the research of Ahmedova (2015) who found that human resources, innovation, and internalization affect the competitiveness of SMEs in Bulgaria. Without 
creativity and innovation, Small Micro Enterprises could not be able to increase their productivities (Darwanto 2013 and Setyanto et al. 2015). Moreover, competitiveness improvement is not only influenced by internal factors but also highly influenced by external factors although this statement is in contrast with the study examined by Sakur (2011) that government role is not positively affect performance development of Small Micro Enterprises in Surakarta.

The competitiveness level of Small Micro Enterprises is determined by the actor itself. In accordance with gender aspect, SMEs operated by women are generally less competitive than those by men. This argument is in line with the finding of Bekele and Worku (2008) that SMEs operated by men entrepreneur are better than women entrepreneur. Some of main factors causing this condition are education level, courage, and assiduous level. Generally, male actors of SMEs have higher level of education, braver to take risk, and more assiduous in doing their business. On the contrary, female actors are generally risk averse and tend to make their business not as a main job, but only as additional work to increase their family income.

Latif et al. (2011) who examined women entrepreneur of Small Micro Enterprises in Sind found that women in rural area actually have a big potential in running various business. However, they still have lack of confidence so they solely doing their business on their own home. The Asia Foundation (2013) investigating SMEs women entrepreneur in Philippine, Malaysia, and Thailand found that women entrepreneurs have not been able to compete in the economy of APEC because of weak formal network, lack of financial access, social culture, and safety aspect. This finding is in accordance with the research of Zhu and Kuriyama (2016) about Gender-related Constraints Faced by Women-owned SMEs. In addition, some empirical studies (González 2016, Orser et al. 2010, and Stoyanovska 2001) also found that women-owned SMEs competed lower than men in global market. Other factors which also significantly affecting business competitiveness of women is information technology. This statement is supported by Siswanto (2009) who found that the development of Batik SMEs by women is need to be complemented by the utilization of information technology. Digital technology is beneficial for women entrepreneurs, especially in accessing markets and interacting with consumers and partners (Pergelova et al. 2019).

\section{Methodology}

This study used a survey approach conducted in two districts in South Sulawesi. Determination of the sites was carried out through some stages including, first, choosing two coastal districts which have became fisheries production centers, namely Bone Regency and Jeneponto Regency. Then, one sub-district was chosen in each district and two villages were selected from each sub-district. The majority of communities worked on fisheries and marine life sector. The unit of analysis is women/women's groups in sample villages who had small microenterprises processing raw materials from fisheries and marine sources

The type of data analyzed here was primary data collected through in-depth interview using open questionnaires as instruments. Those data include types of small micro-businesses, raw materials, number of workers, production costs, product prices, average income earned, product quality, processing/technology techniques, access to local resources, access to the market, and support for local economic institutions, support for local government policies and programs, and the problems and challenges faced. Primary data were analyzed through statistical-descriptive analysis and qualitative techniques.

Results

\section{Micro Small Business Competitiveness Analysis by Coastal Women}

The analysis of the competitiveness of small micro businesses for women on the coast focuses on the internal aspects of SMEs, namely production, types of small micro-businesses, 
income, capital, and markets. The external aspect includes the support of government policies and local institutions. The survey conducted on the coast of Bone Regency and Jeneponto Regency found that the types of small micro-enterprises developed by coastal women varied greatly. However, the types of small micro-businesses can be grouped into four main groups, namely (i) Small micro-businesses processing fish into meatballs, nuggets, shredded, otak-otak, and so on, (ii) Small micro-enterprises processing seaweed into various food such as dodol, crackers, brownies, and others (iii) Small micro-businesses processing fish through fumigation or drying, and making milkfish presto, and (iv) small microbusinesses producing salt.

Based on the survey, it was found that the number of small micro business run by women in the sites was 27 or 44 percent of the total 62 small micro-enterprises. The types of small microbusinesses products made from fish are meatballs, nuggets, shredded rice, shredded crabs, and otakotak. Fish raw materials, besides being processed into meatballs, nuggets, and others, are also processed to be smoked fish, dried fish, and presto milkfish. The number of women working on this type of business was 16 or around 26 percent. Then the number of women or wives of fishermen use seaweed for making various food such as brownies, chips, and dodol was 16 or 26 percent of the total MSEs. Jeneponto Regency is a big salt producer as women who developed salt business were 5 percent of 62 types of small micro businesses.

Small micro businesses which produce various food such as meatballs, nuggets, and brains made from fish, crabs, and shrimp were developed by respondents with an average of 1-5 years. This means that the development of small micro enterprises is relatively new compared to small micro-enterprises such as fish fumigation and fish scraping. The development of some businesses of meatball, nuggets, and otak-otak from fish is based on market demand, which focuses on target teenagers. But the market is still limited to the local area so that the production could not be sustained well. Similarly, seaweedbased food is also a small micro business which is still relatively newly developed which has been for around 2 years. While various ways of how fish is processed such as fish fumigation and drying are generally carried out by women. Respondents had normally run fish fodder and fish drying business for more than 5 years even some respondents experienced up to 20 years. In terms of microbusinesses such as salt, only four coastal women were found to carry out these jobs with an average age of 2-5.

\section{Figure 1: Distribution of Respondents according to the type of Small Micro Enterprises}

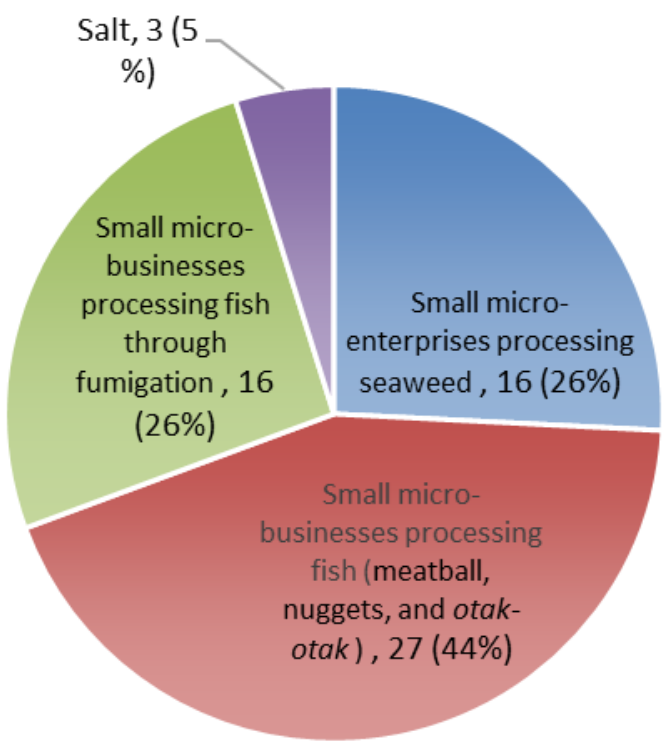


Based on the characteristics of respondents for all small micro business groups, it was found that the level of their education, in general, was still relatively low. This is indicated by the survey indicating that 50.0 percent of respondents graduated from elementary education, 26 percent graduated from junior high school, and 24 percent had studied until high school education. Overall, based on the descriptive statistics analysis, it was found that the average income of respondents from the two sample districts was IDR 2,805,008 per month. The lowest income was IDR 350,000 while the highest was IDR 1,500,000. Based on the average amount of income per month, those amounts seemed to be large because they had exceeded the average minimum wage of South Sulawesi Provinsi that was IDR 2,600,000 in 2018. However, this fact proves that there was a considerable gap shown by the standard deviation of IDR 3,477,593. The amount of income that most often earned from all respondents was IDR 650,000 . This means that the number of respondents who received income of less than IDR 1 million per month was quite a lot which was 40.3 percent. This fact also shows that the money earned by women from small micro enterprises were very low, which affects the competitiveness of the products.

However, some women running MSEs are quite encouraging because they are able to get an average monthly income of IDR 3 million to above IDR 10 million even though their number were still low. This means that from an economic standpoint, the types of MSEs that are run have good prospects. In general, respondents belonging to this income group were the ones continuing the business from their parents, conducting production on a daily basis, and already owning a certain market.

Table 1: Distribution of Respondents according to Average Income Group per Month of Women's SMEs in Sample Locations (Bone Regency and Jeneponto Regency)

\begin{tabular}{lll}
\hline Average & Number of & Percentage \\
\hline
\end{tabular}

\begin{tabular}{lcc}
\hline $\begin{array}{l}\text { Income by } \\
\text { Group/Month }\end{array}$ & Respondents & \\
\hline$<1$ million & 25 & 40.3 \\
$1-2.9$ million & 22 & 35.5 \\
$3-5.9$ million & 6 & 9.7 \\
$6-9,9$ million & 5 & 8.1 \\
$>10$ & 4 & 6.5 \\
\hline
\end{tabular}

In general, it can be concluded that the amount of the income obtained by respondents (coastal women) in the research sites highly depended on several factors: (i) the type of product produced by each small micro business group, (ii) the volume of production, (iii) production processes (technology), (iv) diversity of product by each respondent, (v) prices, and (vi) marketing. After grouping them into four types of small micro business groups, it can be seen that the average income earned by coastal women varied.

Analysis of Small Micro Business of Meatball Processing. In small micro business groups focusing on meatballs and other products similar to that, the average income per month of all respondents was IDR 2.08 million per month. However, the standard deviation and the fairly wide gap indicated that there is a gap in the income among small micro-entrepreneurs. The highest income was IDR 10 million was the lowest one was IDR 600 thousand. The low income earned was mainly due to market access, production volume, and technology which were still very simple. The survey showed that some respondents did a production based on orders such as from a party organizer, exhibitions or other events. Respondents with good access to market can do production produce every day and even sometimes try to create another kind of products other than meatballs like batagor, otak-otak, and abon.

This study found one respondent who marketed products to four primary schools and conducted each school day and also separated some of his production to sell around his home. A fairly good market has led respondents to develop 
various types of products. Other respondents who get high income were mostly also caused by the diversity of the types of products and technologies used.

Based on the use of technology, it appears that respondents with low income also rarely use technology. Processing raw materials into semifinished materials and final products still tended to use simple technology so that their production capacity was still limited. For example, shredded crab production was still conducted by human rather than machine especially in removing the contents of crab. The same condition happened to the production of Abon tuna and meatballs from milkfish. In making fish meatballs, some respondents still used fruit blenders so that their production capacity was very limited. The survey results showed that the average production for processing fish into meatballs and nuggets per day was 43 packs. Each pack has a different volume, but in general, each pack contains 100 grams. The price per pack for 100 grams ranged from IDR 10,000 to IDR 15,000 . While a package with 200 grams of meatballs had the prices between IDR 20,000 and IDR 50,000. The determination of price is not solely based on volume but based on the types of raw materials used. Some products of meatballs, nuggets, otak-otak, and abon use relatively expensive raw materials such as shrimp, crabs, mackerel fish, and tuna. While products using milkfish or flyingfish generally had the price of IDR 10,000 which is relatively cheaper.

The highest income was IDR 10 million while the lowest one was IDR 600 thousand. The number of respondents who received an average income of IDR 10 million was only 1 . The amount of income obtained was affected by the type of product which was quite varied. The diversity of product was supported by the use of technology that was relatively more modern compared to other tools used by other respondents. In addition to product variation factors, the marketing prospects were quite promising. This small business actor had been able to market products outside the region and even the products have been marketed to stores in the Capital District of
Bone Regency. Even so, the obstacles faced were also still quite many, for example, obstacles in obtaining the raw materials so that sometimes the stock was not available. Internally, the type of business they run was highly competitive, but from the external side, the support of government policies related to the availability of raw materials and capital appeared to be limited.

The educational level of respondents, in general, was elementary school education which was 56 percent of the total respondents. They processed fish meatballs and other similar products. The rest graduated from junior high schools (SMP) which were 15 percent and high school which were 29 percent. In terms of the level of education, the survey shows that there is no correlation between education and production volume and income. Indeed, there were even respondents able to innovate and produce in large quantities although just graduated from elementary school.

However, along with the rapid development of innovations and advancement on technological and information, similar products could be also produced by women MSEs lately coming from other areas and possibly had higher competitiveness. This condition highly likely sweep away the market of local products and replaced by products with better innovation and quality. Therefore, the low level of education might become a threat to this condition and it is indeed impossible to support the modern ear. This is in line with Al-Sadi et al. (2011) stating that one of the big challenges faced by women entrepreneur is their educational level which therefore needs training.

In general, micro-entrepreneurs producing bakso had productive ages which were between 20-45 years old and 3-5 year work experiences. This study found a fact that education and age aspects did not really influence the production level. Some respondents had a low educational background but could earn higher income compared to other respondents graduated from junior or senior high schools. 
An important point to observe is the job experiences. In general, respondents who could earn approximately IDR 650,000 monthly were the ones who just started their business. Their work in producing meatball and other similar food had been run for 1-2 years and even some of them for 6 months only. The work experiences also affected the volume produced and access to the market. This study found that there was an indication of the linear relationship between the duration of work and income they earned. The longer the age of small micro businesses and supported by market guarantees, the greater the impact on coastal women to innovate (Njiraini et al. 2018).

Therefore, in improving the competitiveness of the products produced by the MSEs, especially the ones focusing on a fish meatball, the actors needed attention and security of the market. A well-defined market will lead the women in the coastal area to produce more various products and better use of technology. However, it is also important to note that access to the market is determined by the quality of the product.

Table 2: Descriptive Statistics the Average Income of Small Micro Business for Women by Type of Small Micro Business Group

\begin{tabular}{lcccc}
\hline & $\begin{array}{l}\text { SMEs of } \\
\text { Meatball and } \\
\text { Other Similar } \\
\text { Products }\end{array}$ & $\begin{array}{l}\text { SMEs of } \\
\text { Seaweed }\end{array}$ & $\begin{array}{c}\text { SMEs of } \\
\text { Smoked Fish } \\
\text { and Other } \\
\text { Similar Products }\end{array}$ & $\begin{array}{c}\text { SMEs of } \\
\text { Salt }\end{array}$ \\
\hline Mean & $2,085,556$ & $1,933,781$ & $3,465,000$ & $6,463,333$ \\
Standard Error & 492,288 & 754,115 & 859,698 & $2,305,662$ \\
Median & 650,000 & 887,500 & $2,200,000$ & $7,180,000$ \\
Mode & 650,000 & 400,000 & $1,500,000$ & \\
Standard & & & & \\
Deviation & $2,558,003$ & $3,016,460$ & $3,438,791$ & $3,993,524$ \\
& & $12,430,00$ & $13,500,00$ & \\
Range & $9,400,000$ & 0 & 0 & $7,890,000$ \\
Minimum & 600,000 & 350,000 & 600,000 & $2,160,000$ \\
& & $12,780,00$ & $14,100,00$ & \\
Maximum & $10,000,000$ & 0 & 0 & $10,050,000$ \\
& & $30,940,50$ & $55,440,00$ & \\
Sum & $56,310,000$ & 0 & 0 & $19,390,000$ \\
Count & 27 & 16 & 16 & 3 \\
\hline
\end{tabular}

Analysis of Small Micro Business Processing of Smoked Fish. Other types of businesses developed by coastal women that are based on fish are fish fuming, fish drying, and presto milkfish. In this business group, 16 respondents or 22 percent of 62 respondents had an average income of IDR 3.4 million per month. This type of micro business did not show a gap in the average income received as indicated by the standard deviation value which was closer to the average income (mean). Although it was recognized that there were two respondents receiving the lowest income of IDR 600 thousand, others were above IDR 1 million per month.

The size of the income earned by small micro-enterprises in fish fumigation depended on the volume of production (amount of fish), the type of fish raw material, and the type of product produced. Respondents engaged in stingrays and sharks fumigation generally earned higher incomes, in the range of from IDR 6 million to IDR 14 million per month. The type of product 
produced was smoked fish and sold at a price of IDR 10,000 - IDR 15,000 per piece. The number of pieces of fish depended on the size of the stingrays and sharks. While respondents who produced drying fish, milkfish presto, bandeng krispi, tamarind fish (Pallu Cella), and Pindang Ikan, generally had an average income ranging from IDR 600,000 to less than IDR 4.7 million per month. According to the volume of production or the amount of fish processed, the price for each product ranged from IDR 7,500 to IDR 15,000 per head.

What is interesting to observe in small micro-enterprises of fish fumigation was (i) the frequency of production. All respondents conducted production on a daily basis. This shows that the marketing side had no obstacles. But the problem often faced was the limited raw materials, especially for stingrays. (ii) the length of work. 69 percent of the 16 respondents had worked in this small micro business for more than 10 years. This is an indication of the relationship between the length of work and the level of income earned. (iii) education level. In general, fish fodder micro businesses are a hereditary business which was generally run by communities graduated from elementary schools. There were only two micro business actors running milkfish MSEs, graduated from middle and high school. The businesses they run had the ago of ranging from 1-3 years. To encourage an increase in the competitiveness of fish curing, it is necessary to ensure the adequacy of fish raw materials.

Analysis of Small Micro Business Results for Seaweed Processing. Various ways to process fish and other marine products carried out by coastal women indicate that women had played a large role in encouraging household income. This is mainly driven by the development of skills and knowledge of human resources in rural areas, especially in coastal areas. A type of product produced by small scale micro-enterprise which was also widely developed by coastal women in addition to raw fish is food and beverages made from seaweed. The products produced included dodol, brownies, chips, jam, and syrup. Of the 16 respondents engaged in small seaweed micro business groups, 81 percent graduated from junior and senior high school, the rest only had elementary school education. This micro-business was generally run by the productive age group, which was 20-45 years with a length of work ranging from 1-5 years.

In seaweed business groups, the average income earned by respondents was IDR1.9 million per month. The highest income was IDR 12.8 million while the lowest was IDR 350 thousand. Based on the survey, respondents who received an average monthly income of around IDR 350 thousand - IDR 400 thousand were the ones who had just run their business for 1-2 years with one type of product. While respondents who had a high average income produced more various seaweed products and had a higher frequency of production. This means the level of the income depended on the production volume, the variety of products, and the production frequency. While production costs were not included as the main factors to reduce the revenue because the seaweed price was relatively cheaper.

Based on the analysis of the average income obtained by coastal women in general it can be concluded that fishermen women are still very difficult to get out of poverty problems so that women are still more dominantly categorized as poor (Lesetedi 2018).

Analysis of Small Micro Salt Business. Small micro-businesses producing salt were only found in Jeneponto Regency. The size of the income depended on the area cultivated and the volume of production. Based on the survey results, each respondent processed 7 to 9 plots and each plot had a different area. Salt production was largely determined by the weather, so sometimes the same area of arable land could provide a different volume of salt. The study found two respondents each processing 9 plots, but the production was different. One respondent produced 2 sacks while the other produced 20 sacks.

What was interesting for small micro-salt businesses was the marketing aspect. At the time 
the survey was conducted, the price of salt was quite more expensive compared to previous years. The price of salt for each sack or $50 \mathrm{~kg}$ is ranged from IDR 80,000 to IDR 100,000. Thus, the average income per month of respondents was IDR 6.4 million. However, the price of salt per sack was very unstable depending on the season and the availability of salt. The average income per month obtained by respondents did not indicate that MSE of salt was better than other types of MSEs.

\section{The Identification of Problems and Challenges Faced by Coastal Women}

Based on the descriptive analysis of data obtained from three small micro business groups in Bone and Jeneponto District, a number of problems and challenges were found. There were a number of problems faced by women entrepreneurs in small micro-enterprises processing fish which were divided into 3 aspects: (i) Inputs of production including raw materials, capital, and human resources; (2) Production technology, and (3) Marketing.

Input Production Aspects. Problems related to production inputs included limited raw materials, the expensive raw material, limited capital, low quality of human resources, and the difficult access to capital. Most respondents stated that raw materials were not available on the local sites and had to be imported from outside the region such as for drying and fumigating fish. All MSEs in fish curing sector processing stingray stated that the prices of raw materials tended to fluctuate and were quite expensive. In general, respondents acknowledged the limited capital as a factor leading to the low production volume. Another internal problem was the institution of the MSEs. It included the organizations/groups of MSEs, human resources (the members of the group), and norms. The survey showed that some MSEs were managed by groups, and others by the individual. Unfortunately, the groups seemed not really functioning well since the members just acted as the labor and received payment after finishing the production. Meaning, the members of the groups did not have a responsibility to increase the competitiveness of the products. In terms of human resources, the majority of them only graduated from elementary schools and just a few managed by women graduating from a higher level of education. Related with the norm aspect, the survey showed that most MSEs which were handled by the group had not regulated a particular norm.

Production Aspect. Problems related to production are also partly raised by a female. Most respondents stated that their production capacity was still low. The production of meatball, nuggets and other similar products generally faced limitations in the amount. The amount of fish processed to be those foods was on average between $2 \mathrm{~kg}-8 \mathrm{~kg}$ per production. There were three main causes of low production volume of meatball were (i) technological support (tools. The use of a simple tool such as small blender machines greatly led to the limited amount of production. The study conducted by Al-Sadi et al. (2011) found seven barriers for women to become entrepreneurs, one of which is the difficulty in accessing technology. (ii) there is no technology supporting the durability of product so that the amount of production is limited, and (iii) raw materials such as shrimp and crabs were often not available. SMEs processing smoked fish got the problem in terms of the limited raw material of stingrays and sharks. While the limited volume of seaweed production in MSE was mainly caused by the uncertainty of the market.

Marketing Aspect. Some problems related to marketing aspects were low product quality, difficult market access, lack of promotion, limited government support, limitation of market objectives to the local level, and low product packaging quality. Nearly 100 percent of women's MSEs processing meatballs, fish fuming, and seaweed faced various problems in the marketing aspects. In the era of openness, MSMEs can only live sustainably through strengthening marketing networks, expanding market areas, and maintaining product characteristics (Andharini 2012). 
Table 3: Problems Faced by Women's Small Micro Business in the Sample Location

\begin{tabular}{ll}
\hline Category & \multicolumn{1}{c}{ Problems } \\
Input & Access to capital is difficult \\
& Limited capital \\
& Quality of Labor (HR) \\
& The low motivation and spirit \\
& in the entrepreneurship \\
& Availability and expensive \\
& price of raw materials \\
The limited amount of \\
Production & production \\
& Low product quality \\
& Simple technology \\
& Difficult access to the market \\
& Lack of Promotion \\
Marketing & Markets at the local level \\
& Limited support from the \\
& government \\
& Low quality of product \\
& packaging
\end{tabular}

Based on the field survey in two research locations, it was found that most respondents had received training from the government. Most of them stated that the motivation to establish a small micro business related to processing fisheries and marine products emerged as the result of training/courses both conducted by the government and by other institutions such as universities. This was in line with An, Ngo Quynh and Kazuyo, Y (2018) that education and training are the drivers of women's empowerment in Vietnam.

\section{Model for Increasing Competitiveness of Small Micro Enterprises of Coastal Women}

Based on the analysis of the real conditions of MSE carried out by women on the coast, it can be concluded that the competitiveness of small micro-enterprises in research locations was still relatively low. This is indicated by the condition of internal aspects of MSEs, such as limited production volume (above 50 percent), low income, limited support of technological innovation, low product and packaging quality, difficulties in accessing capital, and market access. In the external aspects, there was still limited support for policies, programs, and activities to strengthen the marketing network, the collaboration of local institutions, the business skill, and support from universities had not been maximized. So far, there has been involvement from local and tertiary government institutions but still seemed to have not synergized well. One study of female fishing workers in India (Aswathy, and Kalpana 2018) confirmed that entrepreneurial validation of women fishermen through government programs does not guarantee the economic empowerment of women fishermen. In addition, business institutions and community organizations, and local institutions had not had much contact with products produced by MSEs running by women.

Some problems and challenges faced by women running MSEs in coastal areas became a factor lowering their spirit in entrepreneurship. The advancement of technology, communication, and information, and the mobility of products produced by micro-preneur all over Indonesia including the outer villages gave a signal that both men and women running MSe had to improve their creativity and innovation in running the businesses. The importance of entrepreneur orientation in the context of micro and medium business had been was emphasized by Karami, and Tang (2019). Furthermore, by Ismail et al. (2016) found that innovation had a significant effect on the success of entrepreneurs in the single mother in Malaysia. This finding was also in line with Exposito, Sanchis-Llopis (2018) found a significant relationship between innovation and the performance of SMEs in Spanish. OkekeUzodike et al. (2018) asserted that the success of small and medium-sized women's businesses must be driven by individual motivation, innovative thoughts, government and non-government support, and private sector support.

To encourage increased competitiveness of small micro businesses, high technology is needed. Mukherjee (2018) emphasizes that low 
technology will reduce the potential of small and medium micro businesses, reduce product demand, lower product quality, then reduce profit margins. In order to improve the competitiveness of MSE run by coastal women in South Sulawesi, a model for increasing system-based MSE competitiveness has been developed where all the elements forming the competitiveness of MSEs must work together with one another. Those elements include the availability of natural resources, the support of technological innovation, the institution of MSEs including human resources and management, financial support, Research and Development, and Marketing. All of these elements can be provided by regional institutions including government institutions, businesses, educational institutions (colleges), and community organizations. To facilitate business institutions, universities, community organizations to contribute to increasing MSE competitiveness, the role of local governments in the form of policy support was urgently needed.

\section{Figure 2: A Model for Increasing Competitiveness of Small Micro Enterprises Run by Coastal Women}

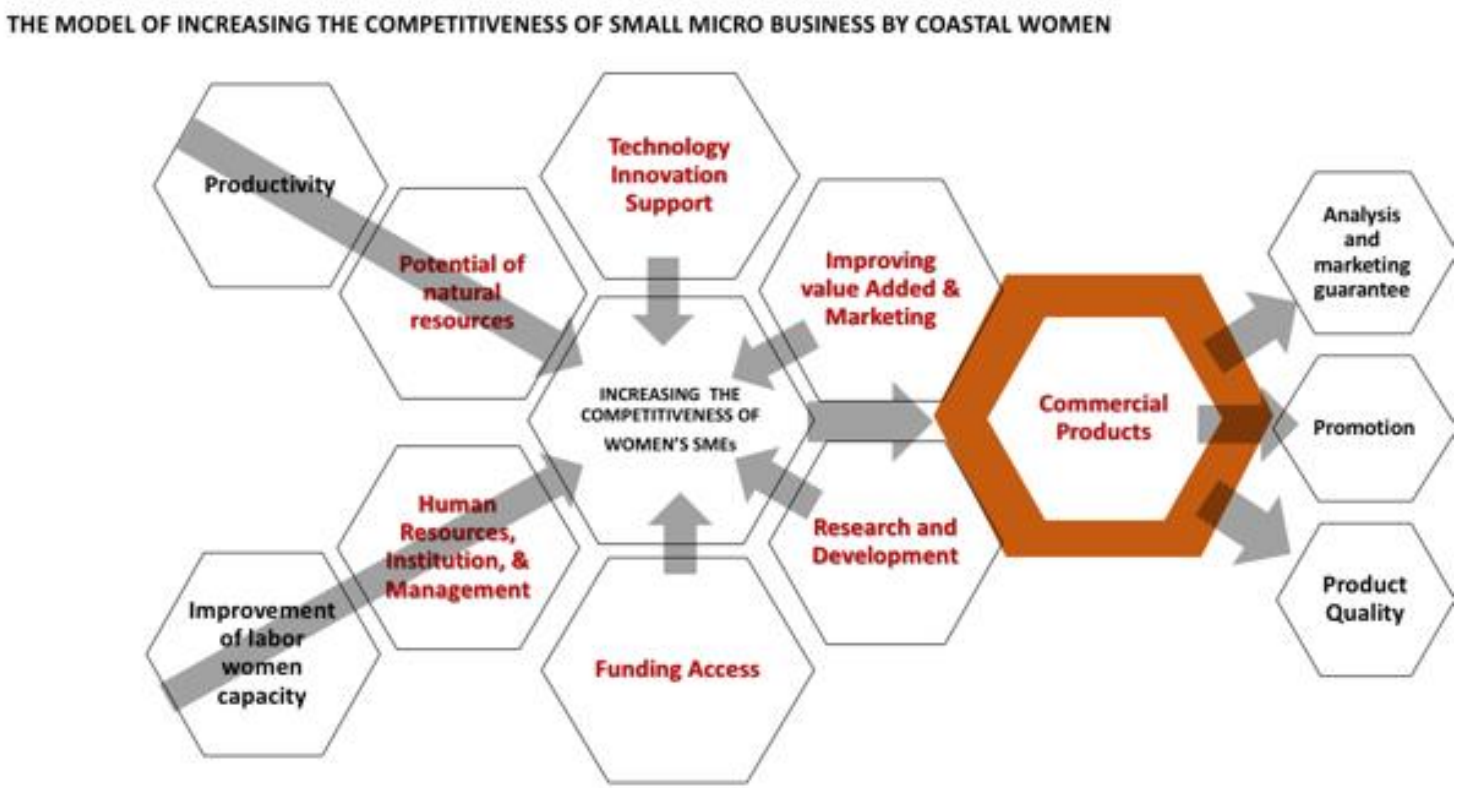

\section{Conclusions and Suggestions}

Small micro-enterprises carried out by women on the coast were quite numerous, but can be grouped into four categories, namely (i) Small micro-businesses processing fish into meatballs, nuggets, shredded, otak-otak, and other similar products, (ii) Small micro-enterprises processing seaweed into various foods such as dodol, crackers, brownies, and other similar products (iii) Small micro-businesses processing fish through fumigation, drying, and presto, and (iv) small micro-businesses in the form of salt productions.

The four groups of MSE each had different competitiveness. But overall it was concluded that the competitiveness of MSE carried out by coastal women was still categorized to be low. This can be seen from the volume of production and the average income per month in general which were still low, and the income gap among MSEs was quite large. This explains that some MSEs earned a high income while others got low.

The low competitiveness of women's MSE products on the coast was highly correlated to a number of problems they faced. Those problems are grouped into three groups, namely (i) aspects of production inputs (ii) Production in terms of volumes and technology used. (iii) Marketing level, and (iv) the low level of institutional 
support includes the ones from the government (policy), business institutions, universities, cooperative institutions, and financial institutions.

In the era of the global economy that is more intensely accompanied by advances in information and communication technology, two important things required including (i) synergism of programs offered by various existing institutions. The synergism of those programs can be reflected in a framework of system-based improvement of SMEs competitiveness, meaning, all supporting elements had to work together so that MSE products can become commercial products. As a result, MSE products would get market guarantees and certainty, can be easily advertised, and guaranteed the product quality. (ii) improve and develop the creativity and innovation of women running MSEs and the entrepreneurship of women living in the coastal areas.

\section{Acknowledgement}

The author would like to thank the Ministry of Research, Technology, and Higher Education Directorate General of Research and Development Strengths that has provided financial support through national competitive grants in conducting research to publication of articles. Address correspondence to: Nursini Nursini, Faculty of Economics and Business, University of Hasanuddin Makassar South Sulawesi, Phone (+62-0411-585415; $583678 . \quad$ E-mail: nini_mahmud@yahoo.com

\section{References}

[1] Agyapong, Daniel (2010). 'Micro, Small and Medium Enterprises' Activities, Income Level and Poverty Reduction in Ghana - A Synthesis of Related Literature,' In International Journal of Business and Management, 5(12), 196205.

[2] Ahmedova, Sibel (2015).'Factors for Increasing the Competitiveness of Small and Medium- Sized Enterprises (SMEs) in Bulgaria,' Procedia Social and Behavioral Science, 195, $1104-1112$.
[3] Ali, Sharafat; Rashid, Humayun, and Khan, Muhammad Amir (2014). 'The role of small and medium enterprisesistepiand poverty in Pakistan: An empirical analysis,' Theoretical and Applied Economics XXI (4), 67-80

[4] Al-Sadi, Ruqaya; Belwal, Rakesh, and AlBadi, Raya (2011). 'Woman Entrepreneurship in the Al-Batinah Region of Oman: An identification of the Barriers,' Journal of International Women's Studies, 12(3), 5875. https://vc.bridgew.edu/jiws/vol12/iss3/ 5

[5] Andharini, Sri Nastiti (2012). 'Entrepreneur Marketing and Micro, Small and Medium Enterprises' Performance,' Journal of Economics and Business, 3 (2), 121-130.

[6] An, Ngo Quynh and Kazuyo, Yamada (2018). 'Determinants of Female's Employment Outcomes in Vietnam,' Journal of International Women's Studies, 19(5), 95-112. https://vc.bridgew.edu/cgi/viewcontent.cgi ?article $=2047 \&$ context $=$ jiws. Accessed on Aug. 15, 2019

[7] Asia Foundation (2013). 'Access to Trade and Growth of Women's SMEs in APEC Developing Economies: Evaluating Business Environments in Malaysia Philippines $\quad-\quad$ Thailand. https://www.sica.int/download/?86431

Accessed on Aug.15, 2019

[8] Aswathy, P. and Kalpana, K. (2018). 'The

'Stigma' of Paid Work: Capital, State, Patriarchy and Women Fish Workers in South India.' Journal of International Women's Studies, 19(5), 113128. 5/8. Accessed on July 13,2019

[9] Atkinson (2013). 'Competitiveness, Innovation, and Productivity: Clearing Up the Confusion. The Information Technology and Innovation Foundation.

[10] Bappenas-National Development Planning 
Agency (2014). The Analysis Report of MSME's Competitiveness in Indonesia

[11] Baptiste-Cornelis, Therese, and Long, Wendell (2006). 'The Impact of Small Business Enterprises on the Economy of Trinidad \& Tobago,' Economic Impact of SBEs.

[12] Bekele, Eshetu, and Worku, Zeleke (2008). 'Women Entrepreneurship in Micro, Small and Medium Enterprises: The Case of Ethiopia,' Journal of International Women's Studies, 10(2),3-19

[13] BPS-Central Bureau of Statistics. Statistic of Indonesia (2018)

[14] Darwanto (2013). 'Competitiveness Improvement of MSMEs Based on Innovation and Creativity (A Strategy To Strengthen Property Right toward Innovation and Creativity),' Journal of Economics and Business, 20 (2). 142-149

[15] Expósito, Alfonso, and Juan A. SanchisLlopis (2018). 'The effects of Innovation on the decisions of exporting and/or importing in SMEs: empirical evidence in the case of Spain," Working Papers 1814, Department of Applied Economics II, Universidad de Valencia. https://ideas.repec.org/p/eec/wpaper/1814. html. Accessed on April 17, 2019

[16] González, A (2016). 'How Does Gender Affect the Participation of SMEs in International Trade?" Keynote Speech Delivered at Queens University, Kingston, Canada, 16 October. accessed august 10, 2018. http://www.intracen.org/news/Howdoes- gender-affect-the-participation-ofSmes- in-international-trade/.

[17] Hamzani, and Achmad (2016). 'The Performance of Micro, Small and Medium Enterprises (MSMEs): Indigenous Ethnic Versus Non-Indigenous Ethnic,' In $3^{\text {rd }}$ Global Conference on Business and Social Science-2015, GCBSS-2015, 16-17 of December 2015. Pp: 265-271.

[18] Indonesian Bank (2016). Mapping and Strategy for Improving the
Competitiveness of MSMEs in Facing the ASEAN Economy Community (MEA) 2015 and Post MEA 2025.

[19] Ismail, Irwan; Husin, Norhusniyati; Abdul Rahim, Najihah; Mohd Kamal, Malina Hanum; and Che Mat, Rosfatihah (2016).' Entrepreneurial Success among Single Mothers: The Role of Motivation and Passion,' Procedia Economics and Finance 37. $121-128$

[20] Karami, Masoud; Tang, Jintong (2019). 'Entrepreneurial orientation and SME international performance: The mediating role of networking capability and experiential learning,'International Small Business Journal: researching Enterpreneurship. 37 (2); 105-124 https://doi.org/10.1177/026624261880727 5

[21] Latif, A., Suhail, M., Assistant, N., Shah, N. (2011). 'Women Entrepreneur in Small Medium Enterprises (SMEs) and their Contribution on Sustainable Economic Development in Sindh,' Journal of Sustainable Development 4(4). DOI: $10.5539 /$ jsd.v4n4p230. Retrieved on 5 August 2019.

[22] Lesetedi, Gwen N (2018). 'A Theoretical Perspective on Women and Poverty in Botswana,' Journal of International Women's Studies, 19(5), 193-208. http://vc.bridgew.edu/jiws/vol19/iss5/13

[23] Mukherjee, Sonia (2018). 'Challenges to Indian micro small scale and medium enterprises in the era of globalization,' Journal of Global Entrepreneurship Research, $\quad 8(28) \quad 1-19$. https://doi.org/10.1186/s40497-018-01155

[24] Niode, Idris, Yanto (2009). 'Micro, Small and Medium Enterprises' Sector in Indonesia: Profile, Problems, and Empowerment,'Journal of Economics and Business OIKOS-NOMOS, 2 (1).

[25] Njiraini, Peter; Gachanja,Paul; Omolo, Jacob (2018). 'Factors influencing micro 
and small enterprise's decision to innovate in Kenya, Journal of Global Entrepreneurship Research 8(34). https://doi.org/10.1186/s40497-018-01324

[26] Okeke-Uzodike, Obianuju E; OkekeUzodike, Ufo; and Ndinda, Catherine (2018). 'Women Entrepreneurship in Kwazulu-Natal: A Critical Review of Government Intervention Policies and Programs,' Journal of International Women's Studies, 19(5), 147-164. https://vc.bridgew.edu/jiws/vol19/iss5/10

[27] Orser, B., M. Spence, A. Riding, and C. A. Carrington (2010). 'Gender and Export Propensity,' Entrepreneurship Theory and Practice 34(5), 933-957.

[28] Pergelova, Albena; Manolova, Tatiana; Simeonova-Ganeva, Ralitsa; and Yordanova, Desislava 2019. 'Democratizing Entrepreneurship? Digital Technologies and the Internationalization of Female-Led SMEs,' Journal of Small Business Management 57(1), 14-39

[29] Porter, M.E. (1990). 'From Competitive Advantage to Corporate Strategy. Boston: Harvard Bussines Review, https://hbr.org/1987/05/from-competitiveadvantage-to-corporate-strategy.

[30] Putu Darya, I Gusti (2012). 'The Effect of Environment Uncertainty and Entrepreneur Characteristic on Enterprises's Competence and Micro, Small and Medium Enterprises' Performance in Balikpapan City,' Journal of Innovation and Entrepreneurship 1 (1). 65-78.

[31] Rahmana, Arief (2009). The Role of Information Technology in Improving the Competitiveness of Micro, Small, and Medium Enterprises. National Seminar of Information Technology Application. http://journal.uii.ac.id/index.php/Snati/arti cle/view/1033. Retrieved on June 12017.

[32] Sakur (2011). 'Study of Factors Contributing to Micro, Small and Medium
Enterprises's Improvement: A Case Study in Surakarta City. Public Spirit 7 (2). 85110.

[33] Samwel, Peter (2014) The Role of Women's Micro-enterprises in Enhancing Rural Households' Access to Basic Needs and Services: Evidence from Fish Selling Micro-enterprises in Kilwa District, Tanzania,' Journal of Education and Practice 5(39), 131-142

[34] Sipa, Monika; Gorze-Mitka, Iwona, and Skibinski, Andrzej (2015), 'Determinants of Competitiveness of Small Enterprises: Polish Perspective,' Procedia Economics and Finance 27. 445 - 453. www. Elsevier.com/locate/procedia

[35] Setyanto, A.R; Samodra, BS, and Pratama, YP. (2015). Strategy of Micro, Small and Medium Enterprises's Empowerment in Facing the Free Trade on ASEAN District (A Case Study Studi in Batik Laweyan Village),' Journal of Etikonomi, 14 (2). 205-220.

[36] Siswanto, Victorianus Aries (2009). 'Study of the Role of Women in the Development of Small and Medium Enterprises through Information Technology in Pekalongan City,' Informatic Dynamics -I (1). 70-77

[37] Stoyanovska, Antonina (2001). 'Jobs, gender and small enterprises in Bulgaria,' ILO Working Papers 993510263402676, International Labour Organization.

[38] Zhu, Huani, and Kuriyama, Carlos (2016). 'Gender-related Constraints Faced by Women-owned SMEs,' Policy Brief. No.15 June 2016. APEC Policy Support Unit. 